\title{
25 Research Square \\ Correlation analysis of MTHFD1 gene polymorphisms and neural tube defects in Han population of Northern China
}

\author{
Yulian Fang \\ Tianjin Children's Hospital https://orcid.org/0000-0003-0136-0078 \\ Yan Liu \\ Tianjin Children's Hospital \\ Jian-Bo Shu \\ Tianjin Children's Hospital \\ Lin-Sheng Zhao \\ Tianjin Children's Hospital \\ Lu Wang \\ Tianjin Children's Hospital \\ Xue-Tao Wang \\ Tianjin Children's Hospital \\ Xiu-Fang Zhi \\ Tianjin Medical University \\ Jie Zheng \\ Tianjin Medical University \\ Ou-Yan Shi \\ Tianjin Medical University \\ Chun-Quan Cai ( $\nabla$ cqcns6@126.com ) \\ Children's Hospital of Tianjin University https://orcid.org/0000-0002-8812-4096
}

Research

Keywords: Neural tube defects, MTHFD1, Polymorphism, gene, Folate metabolism

Posted Date: October 30th, 2020

DOI: https://doi.org/10.21203/rs.3.rs-74880/v1

License: (a) (i) This work is licensed under a Creative Commons Attribution 4.0 International License. Read Full License 


\section{Abstract \\ Background}

Neural tube defects (NTDs) is a common birth defects worldwide. The methylenetetrahydrofolate dehydrogenase1 (MTHFD1) gene has been proved to play an important role in folate metabolism, which was strongly associated with the increased NTDs risk. The study is aimed to explore the correlation of single nucleotide polymorphisms (SNPs) in MTHFD1 gene with NTDs susceptibility.

\section{Methods}

A case-control study was conducted on children who included 152 NTDs patients and 169 healthy controls. Tag-SNPs were identified in HapMap database. Then, we investigated the association between NTDs and four selected tag-SNPs in MTHFD1 gene: rs1950902, rs2236225, rs2236224, rs11849530. We also performed a meta-analysis based on previous published studies to further evaluate the association.

\section{Results}

The results indicated that rs2236225 polymorphism displayed a significant association with NTDs risk (AA $v s$. $\mathrm{GG}: \mathrm{OR}=2.862,95 \% \mathrm{Cl}=1.022 \varangle 8.015 ; \mathrm{GA}+\mathrm{AA} v s . \mathrm{GG}: \mathrm{OR}=1.619,95 \% \mathrm{Cl}=1.040 \otimes 2.520 ; \mathrm{A} v s . \mathrm{G}: \mathrm{OR}=1.500$, $95 \% \mathrm{Cl}=1.061 \otimes 2.120$ ). In addition, rs2236224 polymorphism was correlated with increased NTDs risk (TT vs. CC: $\mathrm{OR}=2.559,95 \% \mathrm{Cl}=1.128 \otimes 5.804 ; \mathrm{CT}+\mathrm{TT}$ vs. $\mathrm{CC} ; \mathrm{OR}=1.631,95 \% \mathrm{Cl}=1.041 \otimes 2.556 ; \mathrm{T}$ vs $\mathrm{C}: \mathrm{OR}=1.489$, $95 \% \mathrm{Cl}=1.072 \varangle 2.068)$. Further analysis showed the harmful effect of rs2236225 polymorphism was further supported by the result of meta-analysis. Meanwhile, haplotype analysis results showed that A-A and T-A haplotypes were correlated with increased NTDs risk, but C-A haplotype might decrease NTDs risk.

\section{Conclusions}

The results indicated that rs2236225 and rs2236224 polymorphisms of MTHFD1 gene were significantly associated with NTDs susceptibility in Han population of Northern China.

\section{Background}

Neural tube defects (NTDs) are congenital malformations of the brain and spinal cord that usually occur in early pregnancy (21区28 days)[1], mainly including spina bifida, anencephaly and encephalocele. As reported, the prevalence is roughly $0.5 \varangle 2$ per 1000 births worldwide, which is higher in China with about 2.74 per 1000 births [2-3]. Related studies had revealed that pathogenesis of NTDs was believed to mainly involve genetic and environmental factors [4-5]. Furthermore, epidemiological studies testified that maternal folic acid supplement can reduce the incidence by $50 \otimes 70 \%$, suggesting that variants in genes involved in folate metabolism pathway may contribute to NTDs risk [6]. Methylenetetrahydrofolate dehydrogenase1 (MTHFD1) plays an important role in folate metabolism by catalyzing the conversion of tetrahydrofolate to the 
corresponding 10-formyl, 5,10-methenyl and 5,10-metheylene derivatives [7]. The MTHFD1 gene is located at chromosome 14q24 and its cDNA contains an open reading frame of $2805 \mathrm{bp}$ that encodes a protein of 935 amino acids [8]. Related studies had indicated that MTHFD1 polymorphisms might be associated with increased NTDs risk, but the association remains controversial since several studies suggest no association. So, the tag-SNPs of MTHFD1 gene were retrieved in our study, including rs1950902 (401A > G), rs2236225 $(1958 G>A), r s 2236224(2136+31 G>A)$, rs1 $1849530(2458-2060 A>G)$ and rs35020344 $(41+239 A>G)$ from the HapMap database based on related criteria. Then, we conducted a case-control study to assess the association between MTHFD1 polymorphisms and the risk of NTDs. Considering the reason for small sample size of an individual study, a further meta-analysis was performed so as to comprehensively evaluate the correlation.

\section{Methods}

\section{Subjects}

All subjects were collected from the Department of Neurosurgery of Tianjin Children's Hospital in China from November 2010 to May 2014. Among them, 152 subjects were diagnosed with NTDs based on clinical manifestations and images. The control group was composed of the other 169 subjects who had the same ethnic background with cases. All participants were from Chinese Han population in the North, Northwest, and Northeast of China. The study protocols were by the Ethical Committee of Tianjin Children's Hospital in China, and the guidelines of the 2000 Declaration of Helsinki and the Declaration of Istanbul 2008 were followed. Written informed consent was obtained from their guardians.

\section{SNPs selection}

In this study, the potential tag-SNPs of MTHFD1 were confirmed by Haploview4.2 software in HapMap database according to the following criteria: Han Population of Northern China; $\mathrm{HW}_{\text {pval }}(P$ value of HardyWeinberg equilibrium test) $>0.05$; MAF (Minor Allele Frequency) $\geq 0.05$. The tag-SNPs selected by Haploview could represent all the genetic variants of MTHFD1 gene.

\section{DNA extraction and genotyping}

Peripheral blood samples were collected from all participants in our study after obtaining their consent. The tubes used to collect peripheral blood contained EDTA as anticoagulation. Extraction of genomic DNA was carried out from blood samples using the Qiagen DNA Blood Mini Kit (Qiagen, UK). The collected DNA samples were stored at $-80^{\circ} \mathrm{C}$ before use. Five tag-SNPs of MTHFD1 gene were genotyped via the Sequenombased Mass ARRAY assay. Then, the data of genotype and allele distributions were incorporated and analyzed by the Filemaker Pro Database, which is a cross-platform relational database application from FileMaker Inc [9].

\section{Statistical analysis}

All statistical analysis were performed by SPSS19.0 software. Statistical significance was accepted at $P \leq$ 0.05 . The $t$-test and Chi-square test were used to estimate the difference in clinical characteristics, genotype and allele distributions between cases and controls. Hardy-Weinberg equilibrium was assessed by Chi-square 
in the control group in order to detect group representation. Then, meta-analysis of all relevant studies on the correlation between MTHFD1 G1958A polymorphism and NTDs risk was conducted by Stata 12.0 software. The pooled OR were calculated under five genetic model to comprehensively assess the correlation. In metaanalysis, heterogeneity among studies was analyzed by Chi-square test-based Q-statistic. The pooled OR was calculated by fixed effect model when $P$ value was more than 0.1 ; otherwise, the random effects models was applied. Moreover, the online SHEsis software ((http://analysis2.bio-x.cn/myAnalysis.php) was used to analyzed the linkage disequilibrium (LD) and haplotype construction. $D^{\prime}$ and $r^{2}$ were calculated for LD analysis.

\section{Results}

\section{Study characteristic}

In our research, 321 subjects were recruited, including 152 NTDs patients (87 males and 65 females) and 169 healthy controls (90 males and 79 females). As shown in Table 1, the average age in NTDs cases and healthy controls were $2.36 \pm 1.21$ and $2.41 \pm 1.30$, respectively, but the difference did not reveal any statistical significance $(P=0.722)$. Importantly, compared with healthy controls, NTDs cases appeared to have higher concentrations of homocysteine and SAH ( $P=0.010$ and $P=0.012)$. Moreover, the level of SAM in NTDs cases was lower than healthy controls $(P=0.021)$. In addition, we found a lower level of folate in NTDs cases compared with healthy controls, but the difference showed no statistical significance $(P=0.063)$.

Table 1

Characteristics of cases and controls

\begin{tabular}{|c|c|c|c|}
\hline & $\operatorname{NTDs}(\mathrm{N}=152)$ & Control( $(\mathrm{N}=169)$ & $P$ Value \\
\hline Age(years) & $2.36 \pm 1.21$ & $2.41 \pm 1.30$ & 0.722 \\
\hline \multicolumn{4}{|l|}{ sex } \\
\hline male & $87(57 \%)$ & $90(53 \%)$ & \multirow[t]{2}{*}{0.474} \\
\hline female & $65(43 \%)$ & $79(47 \%)$ & \\
\hline Folate(nmol/L) & $8.8 \pm 1.5$ & $9.4 \pm 1.8$ & 0.063 \\
\hline Homocysteine $(\mu \mathrm{mol} / \mathrm{L})$ & $9.5 \pm 1.6$ & $8.8 \pm 1.6$ & 0.010 \\
\hline SAM(nmol/L) & $51.1 \pm 2.6$ & $52.2 \pm 2.7$ & 0.021 \\
\hline $\mathrm{SAH}(\mathrm{nmol} / \mathrm{L})$ & $10.5 \pm 1.4$ & $9.8 \pm 1.6$ & 0.012 \\
\hline SAM/SAH & $4.9 \pm 0.6$ & $5.5 \pm 0.9$ & $<0.001$ \\
\hline \multicolumn{4}{|c|}{ Note: SAM, S-adenosylmethionine; SAH, S-adenosylhomocysteine. } \\
\hline
\end{tabular}

Five tag-SNPs were identified from HapMap database according to above criteria. The LD plot of five tagSNPs was presented in Fig. 1. Because rs35020344 site did not conformed to Hardy-Weinberg equilibrium 
test, four tag-SNPs (rs1950902, rs2236225, rs2236224 and rs11849530) were selected by Haploview 4.0 to represent all SNPs in MTHFD1 gene. The SNPs of rs1950902 and rs2236225 were located in the exons, whereas the SNPs of rs2236224 and rs11849530 were situated in introns.

\section{Association between haplotypes of MTHFD1 gene and the risk of NTDs}

The haplotype was constructed to analyze the effect of the LD on NTDs in Han population of Northern China. Our results indicated that there was a statistical significance in haplotype A-A, C-A and T-A between the two groups $(P<0.05)$. The OR with 95\%Cl of A-A and C-A haplotypes were 1.951(1.057-3.600) and 1.529(1.0412.246), suggesting that they were harmful factors for NTDs. However, the OR with $95 \% \mathrm{Cl}$ of T-A haplotype was 0.682(0.497-0.93), indicating it was a protective factor for NTDs (Table 2).

Table 2

Haplotype analysis results

\begin{tabular}{|lllllll|}
\hline Haplotype & Cases (\%) & Conrols (\%)t & $\chi 2$ value & $P$ values & OR values & $95 \% \mathrm{Cl}$ \\
\hline block 1 & & & & & & \\
\hline A-A & $15(9.7)$ & $9(5.2)$ & 4.710 & 0.0300 & 1.951 & $1.057-3.600$ \\
\hline A-G & $23(15.1)$ & $31(18.2)$ & 1.042 & 0.3075 & 0.804 & $0.529-1.223$ \\
\hline G-A & $34(22.8)$ & $32(19.0)$ & 1.334 & 0.2481 & 1.252 & $0.855-1.835$ \\
\hline G-G & $79(52.4)$ & $97(57.6)$ & 1.726 & 0.1890 & 0.811 & $0.594-1.109$ \\
\hline block 2 & & & & & & \\
\hline C-A* & $57(37.5)$ & $79(46.8)$ & 5.682 & 0.0172 & 0.682 & $0.497-0.935$ \\
\hline C-G & $36(24.0)$ & $40(23.6)$ & 0.015 & 0.9027 & 1.023 & $0.711-1.472$ \\
\hline T-A* & $37(24.3)$ & $29(17.4)$ & 4.722 & 0.0298 & 1.529 & $1.041-2.246$ \\
\hline T-G & $22(14.2)$ & $21(12.2)$ & 0.532 & 0.4659 & 1.186 & $0.750-1.874$ \\
\hline
\end{tabular}

\section{Association between MTHFD1 polymorphisms and the risk of NTDs}

Table 3 showed the distribution of genotype and allele frequencies. We found a significant association between MTHFD1 rs2236225 and the risk of NTDs. In homozygous comparsion (AA vs. GG), the frequency of AA genotype was higher in the case group than that of controls, and the difference was significant (OR = 2.862, 95\%Cl: 1.022 8.015). Under the dominant model (GA+ AA vs. GG), children carrying GA and AA genotypes had greater risk of NTDs compared with individuals with GG genotype $(\mathrm{OR}=1.619,95 \% \mathrm{Cl}$ : 1.040 2.520). Under allele model (A vs. G), comparision of A allele frequency revealed a statistically significant difference between the two groups (OR $=1.500,95 \% \mathrm{Cl}: 1.061 \rrbracket 2.120)$. 
Table 3

The results of association between MTHFD1polymorphisms and NTDs risk

\begin{tabular}{|c|c|c|c|c|}
\hline Genotypes & Cases $(N=152)$ & Controls $(\mathrm{N}=169)$ & $\mathrm{OR}(95 \% \mathrm{Cl})$ & $P$ value \\
\hline \multicolumn{5}{|c|}{ rs1950902 $(401 A>G)$} \\
\hline AA & 12 & 10 & Ref & \\
\hline AG & 52 & 59 & $0.734(0.293-1.840)$ & 0.509 \\
\hline GG & 88 & 100 & $0.733(0.302-1.780)$ & 0.492 \\
\hline$A G+G G$ & 140 & 159 & $0.734(0.308-1.750)$ & 0.484 \\
\hline A allele & 76 & 79 & Ref & \\
\hline G allele & 228 & 259 & $0.915(0.637-1.314)$ & 0.630 \\
\hline \multicolumn{5}{|c|}{ rs2236225(1958G >A) } \\
\hline GG & 65 & 93 & Ref & \\
\hline GA & 74 & 70 & $1.513(0.959-2.384)$ & 0.074 \\
\hline AA & 12 & 6 & $2.862(1.022-8.015)$ & 0.039 \\
\hline$G A+A A$ & 86 & 76 & $1.619(1.040-2.520)$ & 0.032 \\
\hline G allele & 204 & 256 & Ref & \\
\hline A allele & 98 & 82 & $1.500(1.061-2.120)$ & 0.021 \\
\hline \multicolumn{5}{|c|}{ rs2236224 $(2136+31 G>A)$} \\
\hline $\mathrm{CC}$ & 54 & 80 & Ref & \\
\hline СT & 79 & 78 & $1.500(0.942-2.391)$ & 0.087 \\
\hline TT & 19 & 11 & $2.559(1.128-5.804)$ & 0.022 \\
\hline $\mathrm{CT}+\mathrm{TT}$ & 98 & 89 & $1.631(1.041-2.556)$ & 0.032 \\
\hline C allele & 187 & 238 & Ref & \\
\hline T allele & 117 & 100 & $1.489(1.072-2.068)$ & 0.017 \\
\hline \multicolumn{5}{|c|}{ rs11849530(2458-2060A > G) } \\
\hline AA & 54 & 66 & Ref & \\
\hline AG & 80 & 85 & $1.150(0.718-1.844)$ & 0.561 \\
\hline GG & 18 & 18 & $1.222(0.580-2.577)$ & 0.598 \\
\hline$A G+G G$ & 98 & 103 & $1.163(0.739-1.831)$ & 0.514 \\
\hline A allele & 188 & 217 & Ref & \\
\hline G allele & 116 & 121 & $1.107(0.803-1.525)$ & 0.536 \\
\hline
\end{tabular}


Moreover, MTHFD1 rs2236224 polymorphism was associated with increased risk of NTDs. In homozygous comparision (TT vs. CC), children having TT genotype showed an increased risk of NTDs compared with individuals with CC genotype $(\mathrm{OR}=2.559,95 \% \mathrm{Cl}: 1.128 \sim 5.804)$. Under the dominant model (CT + TT vs. CC), children who had CT and TT genotypes were likely to affect NTDs compared with healthy controls $(\mathrm{OR}=$ 1.631, 95\% Cl: $1.041 \otimes 2.556)$. Under allele model ( $T$ vs. C), $T$ allele carriers were shown to be correlated with increased risk of NTDs compared with carrier with $\mathrm{C}$ allele $(\mathrm{OR}=1.489,95 \% \mathrm{Cl}: 1.072 \varangle 2.068)$. Besides, rs1950902 and rs11849530 polymorphisms were not associated with the susceptibility of NTDs (all $P>0.05$ ).

\section{Meta-analysis of the correlation between MTHFD1 1958G > A polymorphism and NTDs risk}

Due to the limitation of sample size, we conducted a meta-analysis of association between MTHFD1 1958G > A polymorphism and the risk of NTDs based on previous studies. A total of seven case-control studies were identified according to the inclusion criterion [10-16].The characteristics of selected studies are summarized in Table 4. As shown in Table 5, MTHFD1 1958G > A polymorphism was significantly associated with increased the risk of NTDs (AA vs. GG: OR $=1.665,95 \% \mathrm{Cl}=1.195 \sim 2.318 ; \mathrm{GA} v s$. GG: $\mathrm{OR}=1.326,95 \% \mathrm{Cl}=$ $1.109 \sim 1.585 ; \mathrm{GA}+\mathrm{AA} v s . \mathrm{GG}: \mathrm{OR}=1.414,95 \% \mathrm{Cl}=1.194 \sim 1.674 ; \mathrm{AA} v s . \mathrm{GA}+\mathrm{GG}: \mathrm{OR}=1.409,95 \% \mathrm{Cl}=1.048$ 1.896; $\mathrm{A}$ vs. G: $\mathrm{OR}=1.307,95 \% \mathrm{Cl}=1.113 \sim 1.534$ ). 
Table 4

Characterisitics of studies included in the meta-analysis

\begin{tabular}{|c|c|c|c|c|c|c|c|c|c|c|}
\hline \multirow[t]{2}{*}{ First author } & \multirow[t]{2}{*}{ Yea r } & \multirow[t]{2}{*}{ Country } & \multirow[t]{2}{*}{ Ethnicity } & \multirow[t]{2}{*}{ Group } & \multicolumn{3}{|c|}{$\begin{array}{l}\text { Genotype } \\
\text { distributions }\end{array}$} & \multicolumn{2}{|c|}{$\begin{array}{l}\text { Allele } \\
\text { frequencies }\end{array}$} & \multirow{2}{*}{$\begin{array}{l}P_{\text {HWE }} \\
\text { for } \\
\text { contro }\end{array}$} \\
\hline & & & & & GG & AG & $A A$ & G & A & \\
\hline \multirow[t]{2}{*}{$\mathrm{Hol}{ }^{[10]}$} & 1998 & Netherland & Caucasian & case & 32 & 55 & 16 & 119 & 87 & \\
\hline & & & & control & 100 & 172 & 63 & 372 & 298 & 0.469 \\
\hline \multirow{2}{*}{$\begin{array}{l}\text { De } \\
\text { Marco }\end{array}$} & 2006 & Italy & Caucasian & case & 25 & 74 & 43 & 124 & 160 & \\
\hline & & & & control & 143 & 251 & 129 & 537 & 509 & 0.367 \\
\hline \multirow{2}{*}{$\begin{array}{l}\text { van der } \\
\text { Linden }^{[12]}\end{array}$} & 2007 & Netherland & Caucasian & case & 31 & 58 & 14 & 120 & 86 & \\
\hline & & & & control & 71 & 98 & 34 & 240 & 166 & 0.985 \\
\hline \multirow[t]{2}{*}{ Doudney ${ }^{[13]}$} & 2009 & England & Caucasian & case & 95 & 133 & 58 & 323 & 249 & \\
\hline & & & & control & 71 & 82 & 33 & 224 & 148 & 0.276 \\
\hline \multirow[t]{2}{*}{$\operatorname{Marini}^{[14]}$} & 2011 & America & Caucasian & case & 50 & 86 & 36 & 186 & 158 & \\
\hline & & & & control & 49 & 69 & 20 & 167 & 109 & 0.587 \\
\hline \multirow{2}{*}{$\begin{array}{l}\text { Prasoona } \\
\text { [15] }\end{array}$} & 2016 & India & Asian & case & 20 & 44 & 56 & 84 & 156 & \\
\hline & & & & control & 50 & 83 & 47 & 183 & 177 & 0.298 \\
\hline \multirow[t]{2}{*}{ Meng ${ }^{[16]}$} & 2015 & China & Asian & case & 31 & 58 & 33 & 120 & 124 & \\
\hline & & & & control & 37 & 48 & 15 & 122 & 78 & 0.930 \\
\hline \multirow{2}{*}{$\begin{array}{l}\text { Current } \\
\text { study }\end{array}$} & 2017 & China & Asian & case & 65 & 74 & 12 & 204 & 98 & \\
\hline & & & & control & 93 & 70 & 6 & 256 & 82 & 0.098 \\
\hline
\end{tabular}


Table 5

Meta-analysis results of association between the MTHFD1 1958G > A polymorphism and NTDs risk

\begin{tabular}{lllll}
$\begin{array}{l}\text { Genetic } \\
\text { models }\end{array}$ & $\begin{array}{l}\text { No. of } \\
\text { studies }\end{array}$ & $\begin{array}{l}\text { Heterogeneity } \\
\text { test }\end{array}$ & $\begin{array}{l}\text { Statistical } \\
\text { model }\end{array}$ & \multicolumn{2}{c}{$\begin{array}{l}\text { Meta-analysis results } \\
\end{array}$} \\
\cline { 2 - 5 } & Pvalue $(\%)$ & & OR(95\%Cl) & $\begin{array}{l}P \\
\text { value }\end{array}$
\end{tabular}

Co-dominant model

$\begin{array}{lllllll}\text { AA vs. GG } & 8 & 0.065 & 47.4 & \text { Random model } & \begin{array}{l}1.665(1.195 \sim \\ 2.318)\end{array} & 0.003 \\ & & & & & \\ \text { GA vs. GG } & 8 & 0.902 & 0.0 & \text { Fix model } & \begin{array}{l}1.326(1.109 \sim \\ 1.585)\end{array} & 0.002\end{array}$

Dominant model

\begin{tabular}{|c|c|c|c|c|c|}
\hline $\begin{array}{l}\mathrm{GA}+\mathrm{AA} v s . \\
\mathrm{GG}\end{array}$ & 8 & 0.520 & 0.0 & Fix model & $\begin{array}{l}1.414(1.194 \sim \\
1.674)\end{array}$ \\
\hline
\end{tabular}

Recessive model

\begin{tabular}{|c|c|c|c|c|c|}
\hline $\begin{array}{l}\text { AA vs. GA+ } \\
\text { GG }\end{array}$ & 8 & 0.041 & 52.1 & Random model & $\begin{array}{l}1.409(1.048 \sim ~ \\
1.896)\end{array}$ \\
\hline
\end{tabular}

Multiplicative model
A vs. G
8
0.045
51.3 Random model
$1.307(1.113 \sim$
$1.534)$
0.001

\section{Discussion}

NTDs are a multifactorial disease and its precise mechanism remains unknown. Epidemiologic studies had confirmed the pathogenesis of NTDs was mainly involved in genetic and environmental factors. A number of studies had demonstrated that variants of several genes involved in the folate-dependent one-carbon metabolism had been shown to be associated with the risk of NTDs [17-18]. Besides, NTDs are associated with polymorphisms involved in planar cell polarity (PCP) signaling pathway [19-21]. Of these, the most important is the gene encoding MTHFD1, which plays an important role in one-carbon metabolism by providing folate cofactors for DNA synthesis and for cellular methylation reactions.

The aim of this study was to explore the association between MTHFD1 polymorphisms and the risk of NTDs. A total of 321 subjects including 152 NTDs cases and 169 healthy controls were enrolled in this study. Related studied showed that low S-adenosylmethionine (SAM), concentration in combination with increased Sadenosylhomocysteine (SAH) concentration had been supposed to reduce methylation capacity [22]. Moreover, many epidemiological studies further confirmed that mothers with NTDs offspring had lower folate and higher homocysteine than those with normal offspring [23]. In our study, comparing the clinical characteristics between case and control groups, there was a significant difference in homocysteine, SAM, SAH and SAM/SAH, which indicated that these factors might be responsible for the occurrence of NTDs. Meanwhile, we selected four tag-SNPs (rs1950902, rs2236225, rs2236224 and rs11849530) to further evaluate the correlation between MTHFD1 polymorphisms and the risk of NTDs. Moreover, we also found that 
A-A (rs1950902-rs2236225) and T-A (rs2236224-rs11849530) haplotypes could increase the risk of NTDs, but C-A (rs2236224-rs11849530) haplotype might reduce the risk of NTDs.

To date, the MTHFD1 rs2236225 is a functional exonic SNP that has been extensively studied in several studies, but the results were inconsistent. Carroll et al reported no evidence concerning correlation between the rs2236225 polymorphism and the risk of NTDs [24]. But Van der Linden et al indicated that G1958A mutation was an important risk factor of NTDs [12].There could be several factors resulting in the conflicting conclusions among individual study. The most likely reasons were the sample size of each study and selected different populations in each study. In our study, we found the rs2236225 polymorphism was significantly associated with increased risk of NTDs. In order to comprehensively evaluate the effect of MTHFD1 rs2236225 polymorphism on NTDs, we conducted a meta-analysis based on previous studies. Meta-analysis results showed a significant association between MTHFD1 rs2236225 polymorphism and the risk of NTDs, which further confirmed the reliability of our findings. Besides, rs2236224 polymorphism is another common genetic variation in MTHFD1, we also found MTHFD1 rs2236224 mutation was associated with increased the risk of NTDs. Etheredge AJ et al reported that the risk of NTDs was significantly increased for infant with MTHFD1 rs2236224 polymorphism, and the results are consistent with ours[25].

\section{Conclusions}

In conclusion, our results revealed that the SNPs of rs2236225 and rs2236224 in MTHFD1 gene were associated with increased NTDs risk in Han population of Northern China. The meta-analysis in our study further supported the conclusion. Due to the limitation of this study, further study with a large sample and functional study should be conducted to get a deeper insight into the etiology of NTDs.

\section{Abbreviations}

NTDs: Neural tube defects; MTHFD1:Methylenetetrahydrofolate dehydrogenase1; SNPs:single nucleotide polymorphisms; LD:linkage disequilibrium; PCP:planar cell polarity; SAM:S-adenosylmethionine; SAH:Sadenosylhomocysteine.

\section{Declarations}

\section{Acknowledgments}

We are grateful to all the participants that contributed to this study and to the staff of Tianjin Children's Hospital for their cooperation and support in the collection of samples. We thank the parents who agreed to participate in the study.

\section{Funding}

This work was supported by the National Natural Science Foundation of China (\#81771589) and the Program of Tianjin Science and Technology Plan (\#18ZXDBSY00170).

\section{Availability of data and materials}


The dataset and analyses are available from the corresponding author on reasonable request.

\section{Authors' contributions}

F-YL, L-Y and S-JB analysed data and drafted the manuscript. Z-LS was responsible for clinical diagnosis.W-L and W-XT were responsible for experimental studies. Z-XF and Z-J were responsible for data collection. O-YS and C-CQ participated in the design and coordination of this study in addition to revising and critiquing the manuscript. All authors read and approved the final manuscript.

\section{Ethics approval and consent to participate}

This study was approved by the Tianjin Children' Hospital Ethics Committee. The guardian (parents) of the patient consented to both participation and publication of the case.

\section{Consent for publication}

Informed consent was obtained from the guardian (parents), who agreed to join this study, and using the medical information for scientific research and publication.

\section{Competing interests}

The authors declare that they have no competing interests.

\section{Publisher's Note}

Springer Nature remains neutral with regard to jurisdictional claims in published maps and institutional affiliations.

\section{References}

1. Kondo A, Kamihira O, Ozawa H. Neural tube defects: prevalence, etiology and prevention. Int J Urol. 2009;16:49-57.

2. Chen X, Guo J, Lei Y, Zou J, Lu X, Bao Y, et al. Global DNA hypomethylation is associated with NTDaffected pregnancy: a case-control study. Birth Defects Res A Clin Mol Teratol. 2010;88:575-81.

3. Greene ND, Stanier P, Copp AJ. Genetics of human neural tube defects. Hum Mol Genet. 2009;18:R113-29.

4. Molloy AM, Brody LC, Mills JL, Scott JM, Kirke PN. The search for genetic polymorphisms in the homocysteine/folate pathway that contribute to the etiology of human neural tube defects. Birth Defects Res A Clin Mol Teratol. 2009;85:285-94.

5. Blom HJ, Shaw GM, den Heijer M, Finnell RH. Neural tube defects and folate: case far from closed. Nat Rev Neurosci. 2006;7:724-31.

6. Berry RJ, Li Z, Erickson JD, Li S, Moore CA, Wang H, et al. Prevention of neural tube defects with folic acid in China. China-U.S. Collaborative Project for Neural Tube Defect Prevention. N Engl J Med. 1999;341:1485-90. 
7. Parle-McDermott A, Kirke PN, Mills JL, Molloy AM, Cox C, O'Leary VB, et al. Confirmation of the R653Q polymorphism of the trifunctional C1-synthaseenzyme as a maternal risk for neural tube defects in the Irish population. Eur J Hum Genet. 2006;14:768-72.

8. Hum DW, Bell AW, Rozen R, Mackenzie RE. Primary structure of a human trifunctional enzyme. Isolation of a cDNA encoding methylenetetrahydrofolate dehydrogenasemethenyltetrahydrofolate cyclohydrolaseformyl-tetrahydrofolate synthetase. J Biol Chem. 1988;263:15946-50.

9. Filemaker Pro Database https://www.filemaker.com.

10. Hol FA, van der Put NM, Geurds MP, Heil SG, Trijbels FJ, Hamel BC, et al. Molecular genetic analysis of the gene encoding the trifunctional enzyme MTHFD (methylenetetrahydrofolate-dehydrogenase,

methenyltetrahy-drofolate-cyclohydrolase, formyltetrahydrofolate synthetase)in patients with neural tube defects. Clin Genet. 1998;53:119-25.

11. De Marco P, Merello E, Calevo MG, Mascelli S, Raso A, Cama A, Capra V. Evaluation of a methylenetetrahydrofolate-dehydrogenase $1958 \mathrm{G}>\mathrm{A}$ polymorphism for neural tube defect risk. J Hum Genet. 2006;51:98-103.

12. Van der Linden IJM, Heil SG, Kouwenberg IC, den Heijer M, Blom HJ. The methylenetetrahydrofolate dehydrogenase (MTHFD1) 1958G > A variant is not associated with spina bifida risk in the Dutch population. Clin Genet. 2007;72:599-600.

13. Doudney K, Grinham J, Whittaker J, Lynch SA, Thompson D, Moore GE, et al. Evaluation of folate metabolism gene polymorphisms as risk factors for open and closed neural tube defects. Am J Med Genet A. 2009;149A:1585-9.

14. Marini NJ, Hoffmann TJ, Lammer EJ, Hardin J, Lazaruk K, Stein JB, et al. A genetic signature of spina bifida risk from pathway-informed comprehensive gene-variant analysis. PLoS One. 2011;6:e28408.

15. Prasoona KR, Sunitha T, Srinadh B, Deepika ML, Kumari TM, Jyothy A. Paternal transmission of MTHFD1 G1958A variant predisposes to neural tube defects in the offspring. Dev Med Child Neurol. 2016;58:62531.

16. Meng J, Han L, Zhuang B. Association between MTHFD1 polymorphisms and neural tube defect susceptibility. J Neurol Sci. 2015;348:188-94.

17. Fang Y, Ma S, Shi O, Zhang P, Cai C. Association between maternal MTHFR C677T polymorphism and neural tube defects in offspring: a Meta-analysis. Tianjin Med J. 2015;43:552-8.

18. Cao L, Wang Y, Zhang R, Dong L, Cui H, Fang Y, et al. Association of neural tube defects with gene polymorphisms in one-carbon metabolic pathway. Childs Nerv Syst. 2018;34:277-84.

19. Cai C, Shi O. Genetic evidence in planar cell polarity signaling pathway in human neural tube defects. Front Med. 2014;8:68-78.

20. Cai CQ, Shi OY, Wang BQ, Chang BX, Yang R, Wang YS, et al. Association between VANGL1 gene polymorphisms and neural tube defects. Neuropeditrics. 2014;45:234-9.

21. Shi OY, Yang HY, Shen YM, Sun W, Cai CY, Cai CQ. Polymorphisms in FZD3 and FZD6 genes and risk of neural tube defects in a northern Han Chinese population. Neurol Sci. 2014;35:1701-6.

22. Yi P, Melnyk S, Pogribna M, Pogribny IP, Hine RJ, James SJ. Increase in plasma homocysteine associated with parallel increasesin plasma S-adenosylhomocysteine and lymphocyte DNA hypomethylation. J Biol 
Chem. 2000;275:29318-23.

23. Steegers-Theunissen RP, Boers GH, Trijbels FJ, Finkelstein JD, Blom HJ, Thomas CM, et al. Maternal hyperhomocysteinemia: a risk factor for neural tube defects? Metabolism. 1994;43:1475-80.

24. Carroll N, Pangilinan F, Molloy AM, Troendle J, Mills JL, Kirke PN, et al. Analysis of the MTHFD1 promoter and risk of neural tube defects. Hum Genet. 2009;125:247-56.

25. Etheredge AJ, Finnell RH, Carmichael SL, Lammer EJ, Zhu HP, Mitchell LE, et al. Maternal and infant genefolate interactions and the risk of neural tube defects. Am J Med Genet A. 2012;158A:2439-46.

\section{Figures}
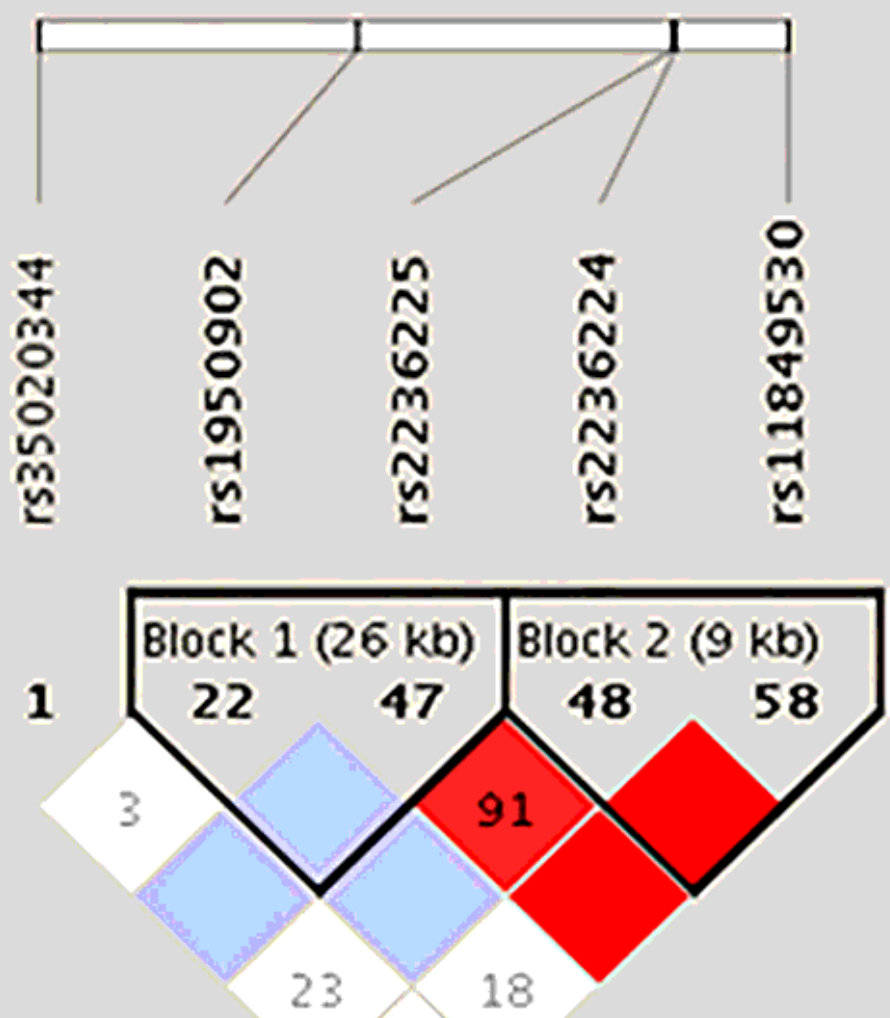

25
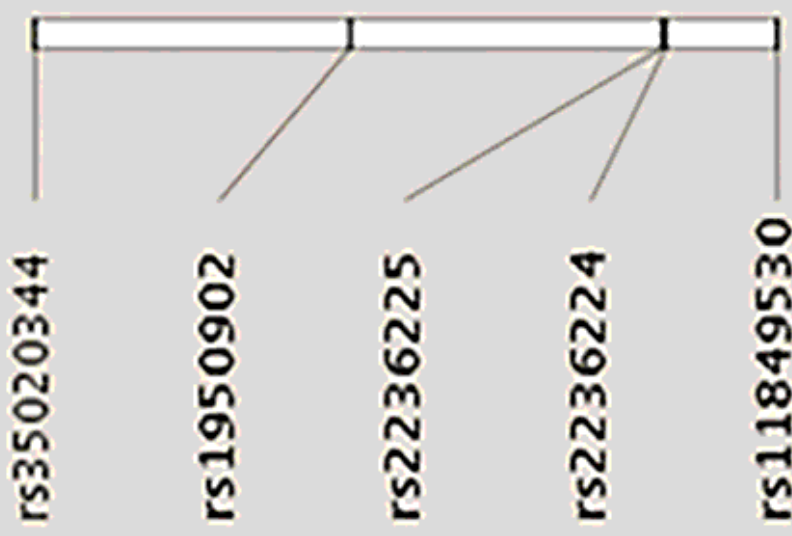

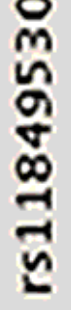

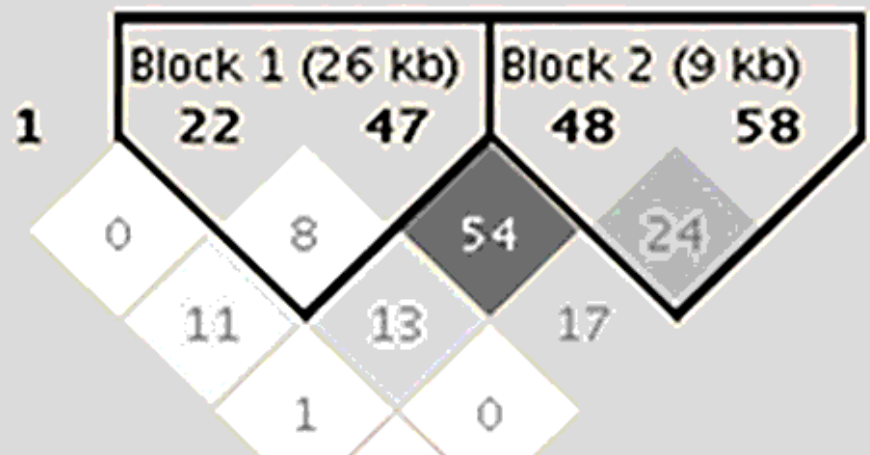

4

\section{Figure 1}

LD information and LD blocks of MTHFD1 gene region. Right figure: color and LD value are shown with D'; left figure: color and LD value are shown with r2. LD block were estimated by Confidence Intervals implemented in Haploview. 